\title{
Short Communication: Ethnobotanical and ecological studies of medicinal plants in a mangrove forest in Mempawah District, West Kalimantan, Indonesia
}

\author{
YANIETA ARBIASTUTIE, ${ }^{1, \boldsymbol{F}}$ FARAH DIBA ${ }^{1}$, MASRIANI ${ }^{2}$ \\ ${ }^{1}$ Faculty of Forestry, Universitas Tanjungpura. Jl. Daya Nasional, Pontianak 78124, West Kalimantan, Indonesia. \\ Tel.: +62-561-739630, Fax.: +62-561-739637, `email: yanieta@fahutan.untan.ac.id, yanietarbiastutie@gmail.com \\ ${ }^{2}$ Department of Chemistry Education, Faculty of Teacher Training and Education, Universitas Tanjungpura. Jl. Prof. Hadari Nawawi, Pontianak 78124 , \\ West Kalimantan, Indonesia
}

Manuscript received: 24 December 2020. Revision accepted: 12 May 2021.

\begin{abstract}
Arbiastutie Y, Diba F, Masriani. 2021. Short Communication: Ethnobotanical and ecological studies of medicinal plants in a mangrove forest in Mempawah District, West Kalimantan, Indonesia. Biodiversitas 22: 3164-3170. The mangrove forest Polaria Tanjung Pagar in Mendalok Village, Mempawah District, West Kalimantan, Indonesia, is a mangrove forest maintained by the local community. Currently, this mangrove forest has become one of the tourist attractions, not only visited by local and national, but also foreign tourists. This study aims to identify plants in Polaria Tanjung Pagar mangrove forest Kalimantan with the potential for medicinal uses. The research used a survey method in the mangrove forest by conducting an inventory of the medicinal plants found in the mangrove forest. Observations were made using a transect line with the total area understudy of 0.012 ha and sampling intensity of $0.4 \%$. The investigation was based on cross-checking the traditional use of medicinal plants by the surrounding communities and the scientific literature. The results showed 13 types of medicinal plants (including tree and understorey plants) from 6 different families, i.e., Acrostichum aureum, Aegiceras corniculatum, Avicennia marina, Avicennia alba, Bruguiera parviflora, Bruguiera gymnorrhiza, Bruguiera cylindrica, Ceriops decandra, Rhizophora apiculata, Rhizophora stylosa, Rhizophora mucronata, Xylocarpus moluccensis, and Sonneratia caseolaris. The community structure of the mangrove forest had moderate diversity for tree species and low diversity for understorey plant species, with an $\mathrm{H}^{\prime}$ valued at 2.39 and 0.25 , respectively.
\end{abstract}

Keywords: Diversity, mangrove forests, medicinal plants, understorey plant

\section{INTRODUCTION}

Forest is a natural storehouse for present and future medicinal plant germplasm diversity (Uprety et al. 2012). Several studies have shown that forests in many parts of the world are sources of traditional medicines which are used especially by forest communities. For example, a survey in Uganda by Tugume et al. (2016) on the communities around Mabira Central Forest showed that 190 species are used as medicines, such as drugs for malaria, hypertension, anemia, and to suppress vomiting. A study in Kakamega forest, Western Kenya, showed 40 plant species that could potentially be used for medicinal purposes for local communities (Otieno and Analo 2012).

Indonesia is known as a mega-biodiversity country, not only at the species level but also at the ecosystem. Each type of forest ecosystem in Indonesia stores a large amount of medicinal plant biodiversity with the ethnobotanical knowledge on medicinal plants is accumulated through a long interaction of local communities with the forest ( $\mathrm{Di}$ Stasi et al. 2002). From legal aspect, the rich diversity of medicinal plants in their natural habitat is protected by the law through the Indonesia Law on Conservation of Natural Resources and Ecosystems (UUKH) No. 5 of 1990 (UUKH, 1990). Nonetheless, such wealth in biodiversity still lacks scientific research in the context of the medicinal aspect. As evidence, among approximately 30,000 types of plants and marine biota, only 940 species are known to have therapeutic (medicinal) properties through scientific research, and about 180 of them have been used by the Indonesian traditional medicine industry (Depkes RI, 2000).

Besides forests on the terrestrial realm, there are forests located in the intertidal zone or so-called mangrove forests. This unique ecosystem is supplied with sea salt water and fresh water from peat swamps (brackish). Mangrove forest is characterized by having a substrate habitat that is muddy, loamy, and sandy, significantly affecting the ecosystem or species that live in the area (Pumijumnong and Uppadit 2012; Schwendenmann et al. 2006). Mangrove forests also show the potentials as sources of medicine, although the existing studies are not as prolific as in the terrestrial forests. For instance, Simlai and Roy (2012) revealed that mangrove plants in the Sundarban Indian Estuary, especially Ceriops decandra, are prospective as medicinal plants because of their phytochemicals antimicrobials activities. More recently, a study on mangrove forests developed in a greenhouse has successfully identified secondary metabolites' potential with medicinal components (Glasenapp et al. 2019).

The largest mangrove ecosystem worldwide can be found in Indonesia, contributing about $27 \%$ of the world's total mangrove forests with a total extent of 16 million ha. In the country, there are 155 mangrove species recorded so 
far, consisting of 89 tree species, two palm species, 19 lianas, 44 epiphytic species, and one cycad species (Bengen 2002). In the regional context of Indonesia, the province of West Kalimantan has the largest mangrove forest area with 119,327 ha and consists of $75 \%$ of the mangrove species of the country. The mangrove forest areas in West Kalimantan are distributed in several districts, including Mempawah, Ketapang, North Kayong, Kubu Raya, Singkawang, and Sambas (SAMPAN Kalimantan, 2015).

The mangrove forest in Mempawah District is a wellknown area of forest ecosystem named Polaria Tanjung Pagar, which is located in Mendalok Village. In this area, the existence of the mangrove vegetation is perceived beneficial by the surrounding communities as they think the mangrove vegetation plays an important role to stabilize the beach by holding back the waves heading for the land, as food sources (e.g., crab, fish, honey, and food ingredients from mangrove leaves), and as construction materials (e.g., housing, canoes, and boats), and as medicines. This study aims to identify plants in the mangrove forest of Polaria Tanjung Pagar, Mendalok Village, Mempawah Regency, West Kalimantan with the potential for medicinal uses. We expect the results of this study could enrich the limited studies on medicinal plants in the mangrove ecosystem by adding the context of a mangrove forest in West Kalimantan.

\section{MATERIALS AND METHODS}

\section{Study area}

The research was conducted in Polaria Tanjung Pagar mangrove forest in Mendalok Village, Mempawah District, West Kalimantan Province, Indonesia. The research site was located at latitude coordinates $0^{\circ} 23^{\prime} 49.65612^{\prime \prime} \mathrm{N}$ and longitude coordinates $108^{\circ} 56^{\prime} 46.38309^{\prime \prime} \mathrm{E}$, and it shows by Figure 1 .
The focused area of this study was located in the equatorial zone with the tropical climate. Based on the nearby Siantan Climatology station report, the average rainfall was 54.7 to $319.3 \mathrm{~mm}$ in 2012 . The humidity in this area tended to be high, about $82 \%-86 \%$ on average and an average air temperature of $26.4^{\circ} \mathrm{C}-27.7^{\circ} \mathrm{C}$ in 2012 .

In this forest, the mangrove biodiversity tends to be stable and well-preserved. Besides being supported by the government, the management of the forest also involves local communities. The local community has long been applying customary rules to protect the mangrove forest ecosystem. Customary regulations are enforced so that mangrove forest management is carried out wisely. Local people and visitors who disturb the forest will be given sanctions either at a minor or major scale. The regulations applied are based on the principle of ecological sustainability conservation. People who deliberately cut down trees without considering the impact are obliged to carry out reforestation actions by replanting one thousand trees as a consequence. Hence, the Polaria Tanjung Pagar mangrove forest can maintain its ecosystem, including the biodiversity therein. Thus, this location is suitable for studying vegetation, including medicinal plants that grow in mangrove forests.

\section{Data collection}

Before collecting data in the field, we surveyed to find the specified location. After identified the location, the path and observation points were determined. Data collection retrieval was carried out by using a specific measuring plot (Oosting 1954).

We used the quadrat transect method with the area under the study of 0.012 ha, sampling intensity of $0.4 \%$ with the sample plot area of $4 \mathrm{~m}^{2}(2 \times 2 \mathrm{~m})$, and a total of 30 plots. Those plots were made systematically with the distance between the sample plots in one stub line of $10 \mathrm{~m}$, while the distance between the stub lines is $100 \mathrm{~m}$. The stub line was made perpendicular to the river.

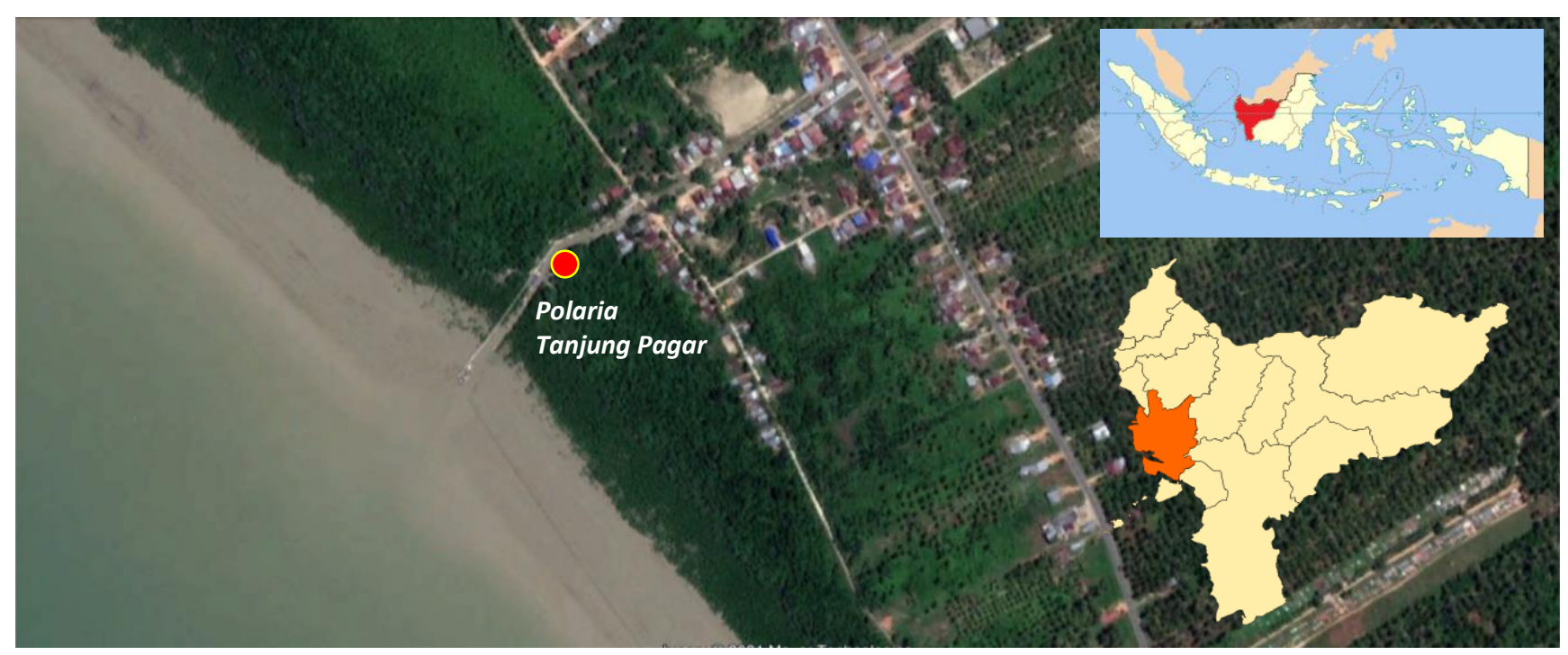

Figure 1. Map of the study area in Polaria Tanjung Pagar mangrove forest in Mendalok Village, Mempawah District, West Kalimantan Province, Indonesia 


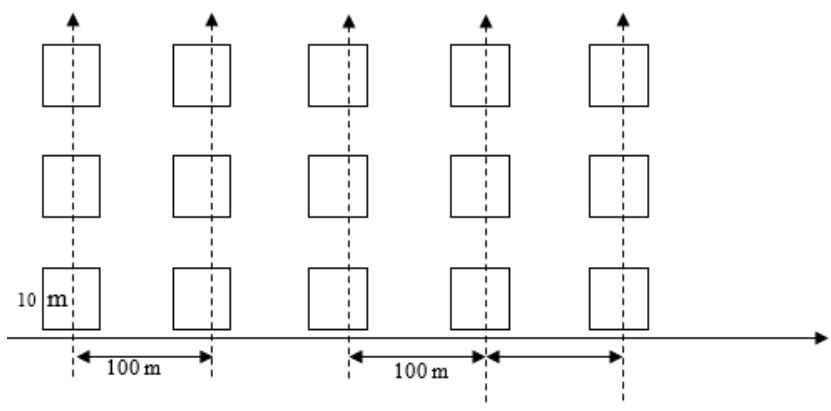

Figure 2. Diagram of transects and observation plots used in the studied site

Data collection was initialized by gathering information on medicinal plants used by local communities. Then, a survey was conducted to identify medicinal plants in the mangrove forest and their use by the local communities. It involved interviews with local communities in obtaining knowledge who have extensive knowledge of medicinal plants. The identification of plant species was based on leave samples. Several references were used to cross-check the information from the respondents regarding their effectiveness as medicine, including monumental books authored by Heyne (1987) about useful plants of Indonesia which consisting four series (i.e., Series 1-4). The unidentified species were collected from the herbarium samples for further identification using the plant identification library.

\section{Data analysis}

The structure and composition of the medicinal plant within the mangrove community were analyzed using the parameters of density, frequency, Important Value Index, and Shannon-Wiener diversity index following Kusmana (1997).

\section{Density \\ Density (D) $=\frac{\text { Number of Individuals }}{\text { Area of the entire sample plot }}$ \\ Relative Density $(\mathrm{RD})=\frac{\text { Density of a species }}{\text { Density of all species }} \times 100 \%$}

Frequency

Frequency $(\mathrm{F})=\frac{\text { Number of plots found for a species }}{\text { Number of plots }}$

Relative Frequency $(\mathrm{RF})=\frac{\text { Species frequency- }-i}{\text { All species frequency }} \times 100 \%$

Important Value Index

IVI = Relative density (RD) + Relative Frequency $(R F)$

Shannon-Wiener Diversity Index

$\mathrm{H}=-\sum[(\mathrm{n} . \mathrm{i} / \mathrm{N}) \log (\mathrm{n} . \mathrm{i} / \mathrm{N})]$

Where: $\mathrm{H}=$ Shannon-Wiener Diversity Index, $\mathrm{n} . \mathrm{i}=$ important value of each species, $\mathrm{N}=$ Total important value

\section{RESULTS AND DISCUSSION}

\section{Results}

Based on our observation, various species of plants in the mangrove forest of Polaria Tanjung Pagar, Mendalok Village, Mempawah District have the potentials for medicinal uses (Table 1). All the plant species used as medicine by residents around the mangrove forest are supported by scientific references. There were 13 species of medicinal plants in the mangrove forest, which habitus of 10 trees, 1 small tree, and 2 shrub trees. They were including Acrostichum aureum L, Aegiceras corniculatum (L.) Blanco, Avicennia marina (Forsk.) Vierh, Avicennia alba Blume, Bruguiera parviflora (Roxb.) W.\& A. ex Griff, Bruguiera gymnorrhiza (L.) Lamk, Bruguiera cylindrica (L.) B1., Ceriops decandra (Griff) Ding Hou, Rhizophora apiculata BI., Rhizophora stylosa Griff, Rhizophora mucronata Lmk, Xylocarpus moluccensis (Lamk) M. Roem, and Sonneratia caseolaris (L.) Engl. Those medicinal plants belong to six families, i.e., Pteridaceae, Myrsinaceae, Verbenaceae, Rhizophoraceae, Sonneratiaceae, and Meliaceae. In total, within the 0.012 ha of the observation plot, the number of medicinal plants in the mangrove forest in Mempawah was about 839 individuals, including tree and understorey plant species. Based on the scientific references, several phytochemical constituents were identified in these plants, including glucoside, saponin, steroid, carotenoid, alkaloid, triterpenoid, flavonoid, tannin, steroid, and polyphenol, which are contributed to supporting health. According to the locals and supported by references, parts of the plants that are being used for medicinal purposes are rhizomes, leaves, sap, flowers, fruit, and bark. People exploit those plants to help stop bleeding, relieve pain, prevent pregnancy, antioxidants, body slimming, wound healing, neutralize poison, appetite enhancer. Also, those plants are used to cure several illnesses, including urine claudin in women, ear infection, herpes, hematuria, smallpox, diarrhea, and bruises on the skin.

Table 2 shows the medicinal tree species found in Polaria Tanjung Pagar Mangrove Forest, in which there were 11 trees used traditionally and supported by scientific documents as medicine. They were including $A$. alba, $A$. marina, B. cylindrica, B. gymnorrhiza, B. parviflora, $C$. decandra, $R$. apiculata, $R$. mucronata, $R$. stylosa, $S$. caseolaris, and $X$. moluccensis. The highest diversity index value was $R$. mucronata with $H^{\prime}=0.242$, which was higher than the average $H^{\prime}$ value, which was 2.39 . While the lowest diversity index value was $B$. parviflora, with $H^{\prime}$ value of 0.194 .

Table 3 shows medicinal understorey plants in this mangrove forest, consisting of $A$. aureum and $A$. corniculatum with an IVI value of 127.74 and 72.26 , respectively. Both plants had biodiversity index value of $H^{\prime}$ $=0.15$ for $A$. aureum and $H^{\prime}=0.09$ for $A$. corniculatum. 
Table 1. Medicinal plants in Polaria Tanjung Pagar mangrove forest, Mempawah District, West Kalimantan, Indonesia

\begin{tabular}{|c|c|c|c|c|c|c|}
\hline Scientific name & Local name & Family & Habitus & Phytochemical property & Part used & Medicinal use \\
\hline Acrostichum aureum & $\begin{array}{l}\text { Paku laut, kerakas, piai } \\
\text { raya }\end{array}$ & Pteridaceae & Tree & Glucoside, saponin, steroid & Rhizome & Stop bleeding, relieve pain \\
\hline Aegiceras corniculatum & Teruntun & Myrsinaceae & Shrub - tree & Saponin & Old leaves & Treating urine claudin in women \\
\hline Avicennia alba Blume & Api-api, sia-sia, unimorf & Verbenaceae & Tree & Carotenoid & Sap & Prevent pregnancy \\
\hline Avicennia marina (Forsk.) Vierh & Pai, nyapi, sia-sia, hajusa & Verbenaceae & Tree & $\begin{array}{l}\text { Alkaloid, triterpenoid, } \\
\text { flavonoid, tannin }\end{array}$ & $\begin{array}{l}\text { Leaves } \\
\text { Bark }\end{array}$ & $\begin{array}{l}\text { Treating sunburn } \\
\text { Birth control contraception }\end{array}$ \\
\hline Bruguiera cylindrica $(\mathrm{L}.) \mathrm{Bl}$ & $\begin{array}{l}\text { Burus, tanjang, lengadai, } \\
\text { lindur }\end{array}$ & Rhizophoraceae & Tree & Tannin & Leaves & Antioxidant \\
\hline Bruguiera gymnorrhiza (L.) Lamk & Sarau, tancang, tumu & Rhizophoraceae & Tree & Steroid, flavonoid & Flower & Treating Ear infection \\
\hline $\begin{array}{l}\text { Bruguiera parviflora (Roxb.) W.\& } \\
\text { A. ex Griff }\end{array}$ & Paproti, bius, lenggadai & Rhizophoraceae & Shrub - tree & Polyphenol & Fruit & Treating herpes \\
\hline Ceriops decandra (Griff) Ding Hou & Parum, tingi, tinci & Rhizophoraceae & Small tree & Tannin & Bark & Body slimming effect \\
\hline Rhizophora apiculata BI. & Bakau minyak & Rhizophoraceae & Tree & Tannin & Leaves & $\begin{array}{l}\text { Wound medicine and neutralize } \\
\text { poison }\end{array}$ \\
\hline Rhizophora mucronata $\mathrm{Lmk}$ & $\begin{array}{l}\text { Blukap, bangko, lului, } \\
\text { tanjang lanang }\end{array}$ & Rhizophoraceae & Tree & Tannin & Bark & Treating hematuria \\
\hline Rhizophora stylosa Griff & Bako-kurap, slindur, & Rhizophoraceae & Tree & Phenol, flavonoid, alkaloid & Fruit & Treating hematuria \\
\hline Sonneratia caseolaris (L.) Engl & Pedada, perepat & Sonneratiaceae & Tree & $\begin{array}{l}\text { Flavonoid, alkaloid, } \\
\text { steroid }\end{array}$ & Leaves & $\begin{array}{l}\text { Medicine for smallpox, diarrhea, and } \\
\text { bruises on the skin }\end{array}$ \\
\hline $\begin{array}{l}\text { Xylocarpus moluccensis (Lamk) M. } \\
\text { Roem }\end{array}$ & Nyirih batu, kabau & Meliaceae & Tree & Steroid & Fruit & Appetite enhancer \\
\hline
\end{tabular}

Table 2. Shannon-Wiener diversity index $\left(H^{\prime}\right)$ of medicinal tree species in Polaria Tanjung Pagar mangrove forest, Mempawah District, West Kalimantan, Indonesia

\begin{tabular}{|c|c|c|c|c|c|}
\hline Scientific name & $\mathbf{N}$ & Number of plot & n.i/N & $\log \mathbf{n . i} / \mathbf{N}$ & $\mathbf{H}^{\prime}$ \\
\hline Avicennia alba Blume & 65 & 22 & 0.08 & -0.21 & 0.21 \\
\hline Avicennia marina (Forsk.) Vierh & 80 & 22 & 0.10 & -0.23 & 0.23 \\
\hline Bruguiera cylindrica (L.) Bl & 79 & 20 & 010 & -0.23 & 0.23 \\
\hline Bruguiera gymnorrhiza (L.) Lamk & 69 & 21 & 0.09 & -0.22 & 0.22 \\
\hline Bruguiera parviflora (Roxb.) W.\& A. ex Griff & 58 & 19 & 0.08 & -0.19 & 0.19 \\
\hline Ceriops decandra (Griff) Ding Hou & 63 & 17 & 0.08 & -0.20 & 0.20 \\
\hline Rhizophora apiculata $\mathrm{BI}$. & 65 & 20 & 0.08 & -0.21 & 0.21 \\
\hline Rhizophora mucronata Lmk & 85 & 30 & 0.11 & -0.24 & 0.24 \\
\hline Rhizophora stylosa Griff & 76 & 21 & 0.010 & -0.23 & 0.23 \\
\hline Sonneratia caseolaris $(\mathrm{L}$.$) Engl$ & 68 & 14 & 0.09 & -0.21 & 0.21 \\
\hline Xylocarpus moluccensis (Lamk) M. Roem & 69 & 12 & 0.09 & -0.22 & 0.22 \\
\hline Total & 839 & & 1.00 & -2.39 & 2.39 \\
\hline
\end{tabular}

Note: N: number of individuals of medicinal plants, H: diversity index. Area of each plot: $2 \times 2 \mathrm{~m} \mathrm{=} 4 \mathrm{~m}^{2}$. The total number of plots: 30 plots, total area sampled $=4 \mathrm{~m} \times 30=120 / 10,000=0.012$ ha 
Table 3. Shannon-Wiener diversity index $\left(H^{\prime}\right)$ and Important Value Index of understorey plants in Polaria Tanjung Pagar mangrove forest, Mempawah District, West Kalimantan, Indonesian

\begin{tabular}{|c|c|c|c|c|c|c|c|c|c|c|}
\hline Scientific name & $\mathbf{N}$ & Number of plot & Diversity & Relative diversity (\%) & Frequency & Relative frequency $(\%)$ & IVI & n.i/N & $\log \mathbf{n . i} / \mathbf{N}$ & $\mathbf{H}$ \\
\hline Acrostichum aureum & 42 & 15 & 3500 & 67.74 & 0.50 & 60.00 & 127.74 & 0.05 & -0.16 & 0.16 \\
\hline Aegiceras corniculatum & 20 & 10 & 1667 & 32.26 & 0.33 & 40.00 & 72.26 & 0.03 & -0.09 & 0.09 \\
\hline TOTAL & 62 & & 5167 & 100 & 0.83 & 100 & 200 & 0.08 & -0.25 & 0.25 \\
\hline
\end{tabular}
x $30=120 / 10,000=0.012$ ha 


\section{Discussion}

Mangrove forest can be defined as a forest type that grows and develops in tidal areas, particularly in river estuaries and sheltered beaches. It is inundated at high tide but uninundated at low tide, and the plant community is tolerant of salt (Jia et al. 2019). The mangrove forest is a community dominated by several tree species that can grow in salty waters (Osland et al. 2013; Sillanpää et al. 2017).

In the mangrove forest of Polaria Tanjung Pagar, Mendalok Village, Mempawah District, there were 13 types of plants from 6 different families, potentially as medicinal plants. Medicinal plants are species of plants believed and understood to possess particular medicinal properties. In general, these properties can be grouped into three, which are: (i) traditional medicinal vegetation, used as raw therapeutic ingredients for traditional medicines; (ii) modern medicinal vegetation, already justified medically and proven scientifically containing bioactive compounds work as medicinal properties, and (iii) potential medicinal vegetation, suspected to possess medicinal attributes but have not been proven scientifically yet.

In this study, investigating the existence of medicinal plants is done by cross-checking the information of people living around the study site and the references that are the basic guidelines in pharmacology. According to the interviews, it was known that the surrounding community has been using plants from mangrove forests since ancient times to support their health. It was also supported by the existence information from valid guidelines references. The part of the plants being utilized for medicinal uses were roots, stems, leaves, bark, flowers, and fruit. Regarding medical efficacy, each of these plant parts is used to treat different diseases, both infectious and non-infectious, including urine claudin in women, ear infection, herpes, hematuria, smallpox, neutralize poison, wound healing, and diarrhea. While, some of them contribute to health as an appetite enhancer, relieve pain, antioxidant source, body slimming, also prevent pregnancy. Empirically, these plant parts contain glycosides, saponins, steroids, carotenoids, alkaloids, flavonoids, tannins, and polyphenols based on pharmacological guidelines references.

According to Petrovska (2012), plants with active substance with therapeutic function can be categorized as medicinal plants. Plants used for their therapeutic properties are found in both cultivated and non-cultivated plants, including mangrove forests. Specific parts of plants are capable of producing various types of phytochemical components. These phytochemical substances are found in very diverse quantities and provide a wide range of pharmacological effects (Sati et al. 2010). The pharmacological effect can be antimicrobial (Anand et al. 2020; Jeevanandam et al. 2017), antioxidant (Khan et al. 2019; Suma and Urooj 2012), antiviral (Ben-Shabat et al. 2020; Chojnacka et al. 2020), anticancer (Shukla and Mehta 2015; Singh et al. 2016), antidiabetic (Teoh and Das 2018; Vinayagam et al. 2017), antihypertensive (Ronchi et al. 2015), neuroprotective (Kumar and Khanum 2012), and so on. It is thought to be due to phytochemical bio components in these natural materials, including tannins, glucosides, saponins, steroids, flavonoids, and triterpenoids, polyphenols, phenols, and others.

The mangrove forest in Polaria Tanjung Pagar, Mendalok Village, Mempawah District was categorized to have a moderate diversity for the medicinal tree species and low diversity for medicinal understorey species, with $\mathrm{H}^{\prime}$ of 2.39 and 0.25 , respectively. The description of a community can be known in various ways, depending on its goals. Community descriptions can be referred to as physiognomy and vegetation analysis, known as plant community. The community description regarding physiognomy is based on the outward appearance of the vegetation. The main physiognomic features of vegetation include tree height, structure, and vegetation growth (Marques et al. 2011). The vegetation community is under the floristic composition in the form of a unit plot containing a group of plants, including medicinal plants. A community is categorized as high species diversity if the community is composed of many species. Conversely, a community is categorized as low species diversity is composed of a few species and only a few dominant species.

Acrostichum aureum and Aegiceras corniculatum were understorey plants with IVI values of 127.74 and 72.26 , respectively. Importance Value Index (IVI) is a quantitative parameter to express the species' dominance level in a plant community. A high IVI value considers dominant species; in contrast, a low IVI value indicates that the observed species have low dominance.

In the development of their life, humans know very well the circumstances around them to sustain his life. One of the beneficial living things around humans is plants which are very important in maintaining human survival. Since ancient times, people have depended on nature for their life. Nature, especially Indonesia, has abundant biodiversity, especially plants. The plant potential has excellent benefits for people's lives. These valuable plants' potential can be classified based on their usage, including foodstuffs, medicines, dyestuffs, animal feed, ornamental plants, crafts, vegetable pesticides, aromatics, firewood, building materials, and for customary uses.

In conclusion, several medicinal plants exist in Polaria Tanjung Pagar mangrove forest with a wide benefit of health. This ecosystem could be one of the natural pharmacies for human being. However, its usage must be appropriate and prioritize the sustainability of the ecosystem to preserve our nature.

\section{ACKNOWLEDGEMENTS}

We thank Universitas Tanjungpura, Pontianak, Indonesia for the financial support of this research.

\section{REFERENCES}

Anand U, Nandy S, Mundhra A, Das N, Pandey DK, Dey A. 2020. A review on antimicrobial botanicals, phytochemicals and natural resistance modifying agents from Apocynaceae family: Possible therapeutic approaches against multidrug resistance in pathogenic microorganisms. Drug Resistance Updates: Reviews and 
Commentaries in Antimicrobial and Anticancer Chemotherapy 51: 100695. DOI: 10.1016/j.drup.2020.100695

Bengen DG. 2002. Introduction and management of mangrove ecosystems. Center for Coastal and Marine Resource Study, Bogor. [Indonesian]

Ben-Shabat S, Yarmolinsky L, Porat D, Dahan A. 2020. Antiviral effect of phytochemicals from medicinal plants: Applications and drug delivery strategies. Drug Deliv Transl Res 10 (2): 354-367. DOI 10.1007/s13346-019-00691-6.

Chojnacka K, Witek-Krowiak A, Skrzypczak D, Mikula K, Młynarz P. 2020. Phytochemicals containing biologically active polyphenols as an effective agent against Covid-19-inducing coronavirus. J Funct Foods 73: 104146. DOI: 10.1016/j.jff.2020.104146.

Depkes RI. 2000. Pedoman Pelaksanaan Uji Klinik Obat Tradisional. Direktorat Jenderal Pengawasan Obatdan Makanan, Jakarta. [Indonesian]

Di Stasi LC, Oliveira GP, Carvalhaes MA, Queiroz-Junior M, Tien OS, Kakinami SH, Reis MS. 2002. Medicinal plants popularly used in the Brazilian Tropical Atlantic Forest. Fitoterapia 73 (1): 69-91. DOI: 10.1016/S0367-326X(01)00362-8.

Glasenapp Y, Korth I, Nguyen XV, Papenbrock J. 2019. Sustainable use of mangroves as sources of valuable medicinal compounds: Species identification, propagation and secondary metabolite composition. South Afr J Bot 121: 317-328. DOI: 10.1016/j.sajb.2018.11.020

Heyne K. 1987. Tumbuhan Berguna Indonesia (Series I-IV). Yayasan Sarana Wana Jaya, Jakarta. [Indonesian]

Jeevanandam J, Aing YS, Chan YS, Pan S, Danquah MK. 2017. Chapter 3 - Nanoformulation and Application of Phytochemicals as Antimicrobial Agents. In: Grumezescu AM (ed.). Antimicrobial Nanoarchitectonics. Elsevier, Nederlands. DOI: 10.1016/B978-0-32352733-0.00003-3.

Jia M, Wang Z, Wang C, Mao D, Zhang Y. 2019. A new vegetation index to detect periodically submerged mangrove forest using single-tide sentinel-2 imagery. Remote Sens 11 (17): 2043. DOI: $10.3390 / \mathrm{rs} 11172043$.

Khan W, Subhan S, Shams DF, Afridi SG, Ullah R, Shahat AA, Alqahtan AS. 2019. Antioxidant potential, phytochemicals composition, and metal contents of Datura alba. BioMed Res Intl 2019: e2403718. DOI: $10.1155 / 2019 / 2403718$

Kumar GP, Khanum F. 2012. Neuroprotective potential of phytochemicals. Pharmacogn Rev 6 (12): 81-90. DOI: 10.4103/09737847.99898

Kusmana C. 1997. Metode Survey Vegetasi. Penerbit Institut Pertanian Bogor, Bogor. [Indonesian]

Marques MCM, Swaine MD, Liebsch D. 2011. Diversity distribution and floristic differentiation of the coastal lowland vegetation: implications for the conservation of the Brazilian Atlantic Forest. Biodivers Conserv 20 (1): 153-168. DOI: 10.1007/s10531-010-9952-4.

Oosting HJ. 1954. The Study of Plant Communities. W.H. Freeman and Company, San Fransisco.

Osland MJ, Enwright N, Day RH, Doyle TW. 2013. Winter climate change and coastal wetland foundation species: salt marshes vs. mangrove forests in the southeastern United States. Global Change Biol 19 (5): 1482-1494. DOI: $10.1111 / \mathrm{gcb} .12126$.

Otieno NE, Analo C. 2012. Local indigenous knowledge about some medicinal plants in and around Kakamega forest in western Kenya. F1000Res 1. DOI: 10.12688/f1000research.1-40.v2
Petrovska BB. 2012. Historical review of medicinal plants' usage. Pharmacogn Rev 6 (11): 1-5. DOI: 10.4103/0973-7847.95849

Pumijumnong N, Uppadit B. 2012. Accumulation of heavy metals in mangrove sediments of Chumphon Province, Thailand. Appl Environ Res 24 (2): 21-38.

Ronchi SN, Brasil GA, do Nascimento AM, de Lima EM, Scherer R, Costa HB, Romão W, Boëchat GAP, Lenz D, Fronza M, Bissoli NS, Endringer DC, de Andrade TU. 2015. Phytochemical and in vitro and in vivo biological investigation on the antihypertensive activity of mango leaves (Mangifera indica L.). Ther Adv Cardiovasc Dis 9 (5): 244-256. DOI: 10.1177/1753944715572958.

SAMPAN Kalimantan, 2015. Rencana Kerja Pengelolaan Hutan Desa Bentang Pesisir Padang Tikar. SAMPAN Kalimantan, Pontianak. [Indonesian]

Sati S, Sati N, Rawat U, Sati OP. 2010. Medicinal plants as a source of antioxidants. Res J Phytochem 4 (4): 213-224. DOI: 10.3923/rjphyto.2010.213.224.

Schwendenmann L, Riecke R, Lara RJ. 2006. Solute dynamics in a North Brazilian mangrove: the influence of sediment permeability and freshwater input. Wetl Ecol Manag 14 (5): 463-475. DOI: 10.1007/s11273-006-0008-1.

Shukla S, Mehta A. 2015. Anticancer potential of medicinal plants and their phytochemicals: a review. Braz J Bot 38 (2): 199-210. DOI: 10.1007/s40415-015-0135-0.

Sillanpää M, Vantellingen J, Friess DA. 2017. Vegetation regeneration in a sustainably harvested mangrove forest in West Papua, Indonesia. For Ecol Manag 390: 137-146. DOI: 10.1016/j.foreco.2017.01.022.

Simlai A, Roy A. 2012. Analysis of and correlation between phytochemical and antimicrobial constituents of Ceriops decandra, a medicinal mangrove plant, from Indian Sundarban estuary. JMPR 6 (32): 4755-4765. DOI: $10.5897 / J M P R 12.657$.

Singh S, Sharma B, Kanwar SS, Kumar A. 2016. Lead phytochemicals for anticancer drug development. Front Plant Sci 7: 1667. DOI: $10.3389 /$ fpls.2016.01667.

Suma PF, Urooj A. 2012. Antioxidant activity of extracts from foxtail millet (Setaria italica). J Food Sci Technol 49 (4): 500-504. DOI: 10.1007/s13197-011-0300-9.

Teoh SL, Das S. 2018. Phytochemicals and their effective role in the treatment of diabetes mellitus: a short review. Phytochem Rev 17 (5): 1111-1128. DOI: 10.1007/s11101-018-9575-z.

Tugume P, Kakudidi EK, Buyinza M, Namaalwa J, Kamatenesi M, Mucunguzi P, Kalema J. 2016. Ethnobotanical survey of medicinal plant species used by communities around Mabira Central Forest Reserve, Uganda. J Ethnobiol Ethnomed 17 (1): 1-28. DOI: 10.1186/s13002-015-0077-4.

Uprety Y, Asselin H, Dhakal A, Julien N. 2012. Traditional use of medicinal plants in the boreal forest of Canada: review and perspectives. J Ethnobiol Ethnomed 8 (1): 1-14. DOI: 10.1186/17464269-8-7.

UUKH. 1990. Undang-Undang No. 5 Tahun 1990 tentang Konservasi Sumberdaya Hayati dan Ekosistemnya. [Indonesian]

Vinayagam R, Xiao J, Xu B. 2017. An insight into antidiabetic properties of dietary phytochemicals. Phytochem Rev 16 (3): 535-553. DOI: 10.1007/s11101-017-9496-2. 